\title{
Remaking The Balkans - In Memoriam Chris (Krsto) Cviić (1930-2010)
}

\section{Sanfey, Peter}

Source / Izvornik: Odabrani prijevodi, 2011, 2, 1 - 9

Journal article, Published version

Rad u časopisu, Objavljena verzija rada (izdavačev PDF)

https://doi.org/10.3326/op.10

Permanent link / Trajna poveznica: https:/urn.nsk.hr/urn:nbn:hr:242:047199

Rights / Prava: Attribution-NonCommercial-NoDerivatives 4.0 International/ImenovanjeNekomercijalno-Bez prerada 4.0 međunarodna

Download date / Datum preuzimanja: 2023-04-26

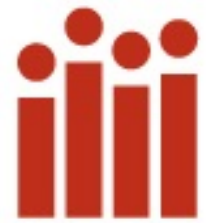




\section{REMAKING THE BALKANS}

Smičiklasova 2I

IO ooo Zagreb

Tel. oI / 4886-444, 4819-363

Fax oI/4819-365

ured@ijf.hr

www.ijf.hr

\section{ODABRANI PRIJEVODI}

\author{
ISSN I847-7445
}

\section{BR. IO/II}

citirati: Sanfey, P., 20II. "Remaking the Balkans". Financial Theory and Practice, $35 \quad$ (2), I39-I47. http://www.ijf.hr/eng/FTP/2OII/2 /memoriam.pdf

Svi Odabrani prijevodi dostupni su na: http:/ / www.ijf.hr/index.php?ime=268

\author{
PETER SANFEY* \\ Europska banka za obnovu i razvoj, London
}

DOI: $10.3326 /$ op. 10

Chris (Krsto) Cviić (1930.-20Io.) svoju je dugu i uspješnu karijeru ostvario kao pisac, komentator, novinar i politički savjetnik. Rođen je 1930. u Hrvatskoj, a I954. došao je u Ujedinjeno Kraljevstvo kako bi radio za BBC u odjelu za jugoslavenski jezik. Godine 1969. pridružio se The Economistu, gdje je 2I godinu radio kao dopisnik za središnju i jugoistočnu Europu. Također je od sredine osamdesetih do 1995. uređivao The World Today, časopis Kraljevskog instituta za međunarodne poslove (smještenog u Chatham Houseu). Godine 1999. Chris je postao viši politički savjetnik EBRD-a za središnju Europu, baltičke države i jugoistočnu Europu. Nakon što je umirovljen u EBRD-u 2007. redovito je objavljivao članke u raznim medijima u Hrvatskojte bio član savjeta hrvatskog predsjednika Ive Josipovića. Chris je napisao dvije knjige o Balkanu na engleskom: Remaking the Balkans, objavljenu I99I., $i$ In Search of the Balkan Recovery: the Political and Economic Re-emergence of South-Eastern Europe (koautor Peter Sanfey), 20Io. Godine 20oI. primio je Red Britanskog Carstva za rad na promicanju demokracije u središnjoj i istočnoj Europi.

Velika mi je čast što sam pozvan održati ovo predavanje u čast i slavu mog dragog prijatelja Chrisa Cviića. Beskrajno sam cijenio naše blisko prijateljstvo i suradnju koja je započela prije dvanaest godina. Nebrojene puno naučio sam od njega, posebno na našim zajedničkim putovanjima po regiji, naročito o povijesti i politici na Balkanu, te kako se poistovjetiti s ljudima i komunicirati s njima.

Chris je bio iznimna osoba u svakom smislu. Imao je želju za znanjem i fenomenalno pamćenje koje je svjedočilo svim interesima kojima se u životu bavio: ljudima i politikom, koja mu je bila strast. Bio je, riječima njegovog bliskog prijatelja Davida Wedgewooda Benna, “osoba nezaustavljive sile”. U EBRD-u je radio u uredu glavnog ekonomista; bio je neekonomist koji je volio biti okružen ekonomistima - to je doista neobično, da ne kažem jedinstveno.

\footnotetext{
* Predavanje posvećeno Chrisu Cviiću, koje je u zajedničkoj organizaciji Europske banke za obnovu i razvoj (EBRD) i Britanskohrvatskog društva održano 6. svibnja 2OII. u sjedištu EBRD-a u Londonu. Zahvaljujem Simone Zeh za pomoć i komentare. Sva iznesena stajališta su moja osobna i ne predstavljaju stajališta EBRD-a.
} 


\section{REMAKING THE BALKANS}

Naslov mog predavanja je "Remaking the Balkans”, što je čist slučaj plagijata iz Chrisove prve knjige objavljene 199I. godine. Želim se prvo osvrnuti na uporabu riječi "Balkan”. U EBRD-u nam se više sviđa pojam "Jugoistočna Europa" i taj pojam koristimo u izvještajima. Međutim, nekako, "Remaking SouthEastern Europe” ne zvuči jednako dobro. Zapravo Chris nije bio zabrinut zbog upotrebe pojma "Balkan" - bio je pravi hrvatski domoljub i neizmjerno ponosan na svoje sjevernohrvatske korijene, no istodobno, kao što je Marcus Tanner ispravno primijetio, "nije suosjećao s tim da mnogi Hrvati pojam ‘Balkan’ doživljavaju uvredljivo”. Doista, Hrvatska ima jedinstven položaj na prijelazu između središnje Europe i Balkana i ima snažne povijesne veze s obje regije.

Razmišljajući o tome što ću reći na ovom predavanju odlučio sam se vratiti Chrisovoj prvoj knjizi koju sam ponovo pročitao. Knjiga potpuno odražava Chrisov poznati stil - remekdjelo lucidnosti, jasnoće i dostupnosti. Poglavlje o gospodarskom razvoju, naslovljeno "gospodarska crna rupa" odlična je analiza gospodarskog nereda koji je $\mathrm{u}$ to doba vladao regijom. Chris je očito mnogo naučio kroz više od dvadeset godina provedenih u The Economistu.

Knjiga je bila vrlo dalekovidna. Na primjer, predvidjela je probleme zemalja na Balkanu i dugotrajnost njihova pridruživanja Europskoj uniji. "Čekanje, osobito na punopravno članstvo u Zajednici moglo bi biti dugotrajno", napisao je, i doista se zapisano ostvarilo - I6 godina čekanja za Bugarsku i Rumunjsku, i još duže za ostale zemlje. Knjiga je predvidjela i mračnu stranu ratnih sukoba na Kosovu. Spominje se i EBRD - Chris je napisao da će nova banka koja je počela poslovati u travnju I99I. "također imati svoju ulogu”, jednom kad "počne poslovati u potpunosti”. To se pokazalo potpuno istinito, Chris je mnogo doprinio našem poslovanju i komunikaciji koju smo ostvarili u regiji.

Knjiga odiše snažnim konstruktivnim duhom. Napisana je u doba kada je bilo očito da se regija raspada, no Chris je bio spreman gledati unaprijed i vidjeti što bi se moglo dogoditi kasnije i kako će regija napredovati. U završnom poglavlju govori o novom izgledu Balkana. Iako njegova vizija spajanja sviju regionalnih grupacija nije u potpunosti ostvarena, njegova analiza i danas važi.

Chris je također bio optimist glede budućnosti Balkana, a to se osjeti i u njegovoj prvoj knjizi, koju je napisao u mračno doba, sredinom 1991. Nekoliko nekrologa o Chrisu osvrnulo se na taj aspekt njegova karaktera i vjerujem da nam to pomaže objasniti zašto je toliko uživao u svom radu. Knjiga završava iznimno važnom izjavom koju vrijedi navesti u cijelosti: "Dobra ostvarenja u gospodarstvu su od velike važnosti jer čine državu jakom i stabilnom. Iako prije prihvaćanja tog načela u Jugoslaviji treba sačekati rješavanje trenutačnog prljavog, ali nužnog procesa ponovne uspostave reda, to će načelo razumjeti novi postkomunistički vođe kao i njihovi narodi i u konačnici će vjerojatno potaknuti suradnju, a ne iredentističke ratove”. Njegov je zapis bio iznimno mudar u doba kada su svi ostali bili zaokupljeni sukobom koji je prijetio regiji. 


\section{U POTRAZI ZA OPORAVKOM BALKANA}

Sada bih želio reći nekoliko riječi o nastanku naše zajedničke knjige. U lipnju 2006. Chris i ja sjedili smo u restoranu u Podgorici, glavnom gradu odnedavno nezavisne Crne Gore i uz čašu, dvije vranca raspravljali o ideji da napišemo novu knjigu - knjigu koja bi se bavila nekim temama iz Chrisove prethodne knjige i dopunila ih, a posebno izjavu koja je ranije naglašena, stavljajući veći naglasak na ekonomski aspekt. Željeli smo napisati nešto čime bismo naglasili napredak koji je ostvaren u regiji, osobito u prvom desetljeću novog stoljeća, srušili neke mitove i nesporazume o Balkanu i naglasili neiskorišteni potencijal regije.

Rezultat je naša knjiga "In Search of the Balkan Recovery: the Political and Economic Re-emergence of South-Eastern Europe” (“U potrazi za oporavkom Balkana: Ponovno političko i gospodarsko stvaranje Jugoistočne Europe”), objavljena u ljeto 20Io. . Za taj smo naslov (i za izdanje knjige) zahvalni izdavaču, Michaelu Dwyeru iz Hurst \& Co. Naslov se odmah dopao i Chrisu i meni jer za regiju koristi nazive "Balkan” i "Jugoistočna Europa” i time rješava dilemu koji naziv treba koristiti te koristi riječi “oporavak" i "ponovno stvaranje”, što su pojmovi koje želimo naglasiti i smatramo da su primjereniji od riječi koje se obično koriste u naslovima knjiga o Balkanu ("kriza”, "sukob” itd.).

Mnogi su od vas bili prisutni na predstavljanju naše knjige u ovom prostoru prošloga ljeta. Neki su od vas možda kupili knjigu, a možda ste je čak i pročitali. Ne želim ponavljati neke stvari koje sam tada rekao. Međutim, želim se vratiti jednoj temi o kojoj smo te večeri kratko raspravljali, a to su ekonomski izgledi Jugoistočne Europe.

\section{NOVI PROGRAM RASTA}

Jugoistočna je Europa teško pogođena krizom. Puni su učinci krize, u usporedbi sa zapadnom Europom i Sjedinjenim Državama, stigli s odgodom, a oporavak će stići jednako polako. Sve su države osim Albanije zabilježile znatan pad BDP-a 2009. Dva najveća gospodarstva - hrvatsko i rumunjsko doživjeli su daljnji pad prošle godine, dok je drugdje rast bio prilično anemičan (u usporedbi sa 4 posto u 20Iо. za cijelu regiju u tranziciji).

Stoga je takav razvoj događanja potaknuo neka nezgodna pitanja. Jesmo li bili pretjerano optimistični u procjenama potencijala naše regije? I je li predkrizni model rasta koji se uglavnom temeljio na rastu trgovine, investicija, financijskoj i političkoj integraciji s ostatkom svijeta bio pogrešan za Balkan?

Odgovori koje bih vam dao, i za koje vjerujem da bi ih Chris podržao da je sada ovdje su: ne i ne. Nismo bili pretjerano optimistični o izgledima za Balkan i iako je opisani model rasta imao slabosti, nije ga potrebno napustiti u potpunosti. No trebali bismo ozbiljno raspraviti o tome kako vratiti Balkan na pravi put, u ekonomskom smislu. Rečeno jezikom EBRD-ovog Transition Reporta za 20Io., potreban nam je novi program rasta, ali ne i novi model rasta. A taj bi novi program rasta zahtijevao da se

\footnotetext{
${ }^{\mathrm{I}}$ Ranije, kraće izdanje knjige bilo je objavljeno 2008. u hrvatskom prijevodu, a izdao ga je Novi Liber press, pod naslovom Jugoistočna Europa: od konflikata do suradnje (South-Eastern Europe: from Conflict to Cooperation).
} 
pozabavimo osnovnim problemima i izazovima koji su donekle gurani ispod tepiha tijekom godina rasta.

Sada bih htio, uz pomoć nekoliko slika, skicirati neke elemente tog novog programa i naglasiti doseg izazova s kojima je regija suočena. Pritom ću zaobići neka neriješena politička pitanja i kontroverze o kojima je Chris tako puno znao i bio tako pronicav. Ne želim umanjiti te probleme, ali vjerujem da je rasprava odlučno usmjerena na ekonomska pitanja.

Regija je suočena s dvama širokim izazovima koje bih želio naglasiti ovom prilikom - poboljšanje životnog standarda (i time smanjenje siromaštva) i usrećivanje ljudi. Očito je da ta dva izazova nisu u potpunosti nepovezana, iako je veza između prihoda i sreće kompleksnija nego što to ekonomski udžbenici pretpostavljaju.

Grafikon I pokazuje koliko Balkan zaostaje za ostatkom Europske unije u visini životnog standarda, predstavljeno BDP-om po glavi stanovnika (2009.) za svaku državu, u usporedbi s prosjekom Europske unije (prilagođeno za kupovnu moć). BDP Albanije po glavi stanovnika jedva prelazi četvrtinu prosjeka Europske unije. Samo Hrvatska među tim zemljama ostvaruje više od 50\% prosjeka Europske unije. Bugarska i Rumunjska ostvarile su 44 odnosno 46 posto prosjeka.

Za većinu zemalja taj se zaostatak vjerojatno neće nadoknaditi za života nas ovdje prisutnih. $\mathrm{Na}$ primjer, pretpostavimo da će Albanija ubuduće ostvarivati rast od 4 posto godišnje, a da će prosjek Europske unije rasti za 2 posto godišnje. Albaniji bi trebalo 65 godina da dostigne prosjek. No, pod povoljnim okolnostima zaostatak je moguće smanjiti s vremenom. Siromašne bi zemlje trebale ostvarivati brži rast od bogatijih, pod uvjetom da se steknu povoljne okolnosti za rast.

\section{Grafikon I.}

Izazov: poboljšanje životnog standarda

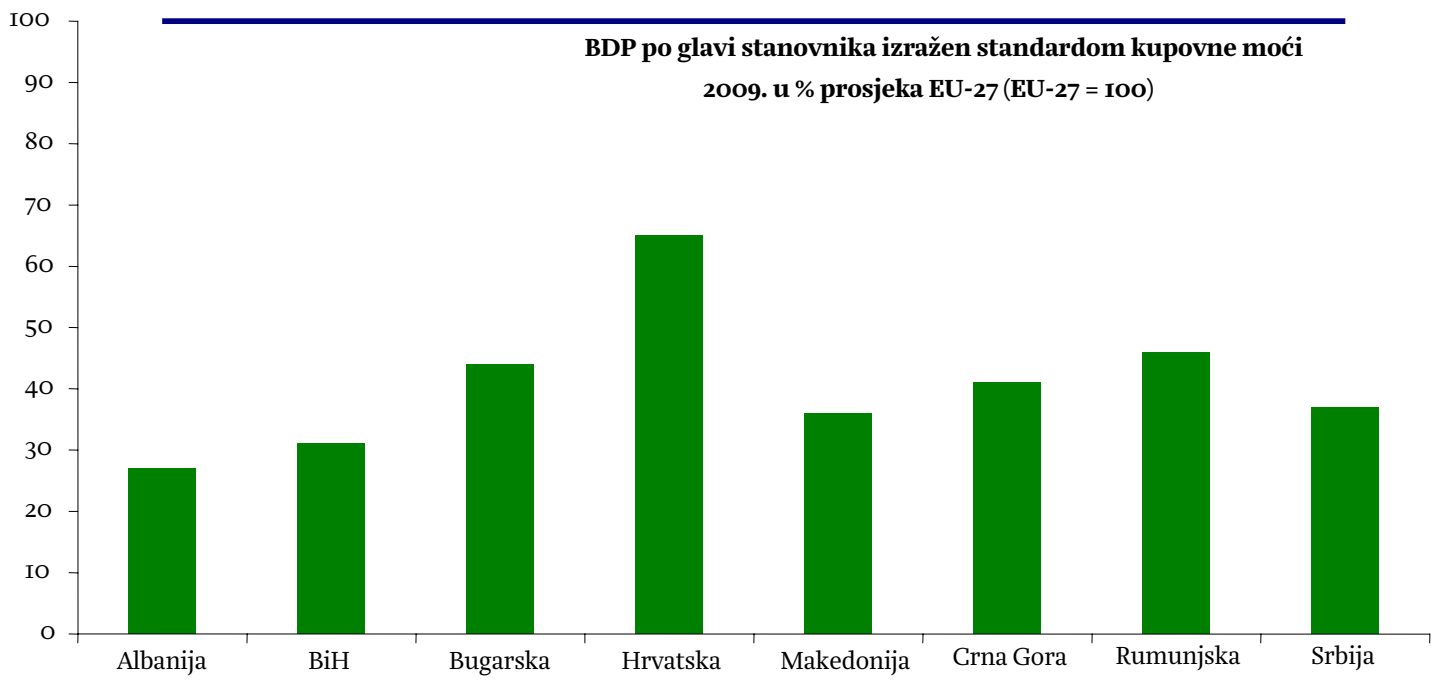

Izvor: Eurostat, 2010. 
Grafikon 2 prikazuje podatke iz ankete Život u tranziciji (Life in Transition) EBRD-a i Svjetske banke iz kojeg je vidljivo koliko su ljudi na Balkanu nezadovoljni životom u usporedbi s ostatkom tranzicijske regije, posebno u usporedbi sa zapadnim zemljama kao na primjer Ujedinjenim Kraljevstvom, Francuskom i Njemačkom. Oko trećine ljudi iz nekoliko republika bivše Jugoslavije složili bi se ili bi se u potpunosti složili s izjavom: "uzimajući sve okolnosti u obzir, zadovoljan sam sa svojim sadašnjim životom”. Iznimka je Hrvatska, iako je čak i ovdje postotak pao ispod 50 posto u razdoblju od 2006. do 20IO. Rezultati za Rumunjsku su zabrinjavajući: samo I8 posto ispitanika izjavilo je da su zadovoljni životom.

\section{Grafikon 2.}

Izazov: učiniti ljude sretnijima (zadovoljstvo životom, \%)

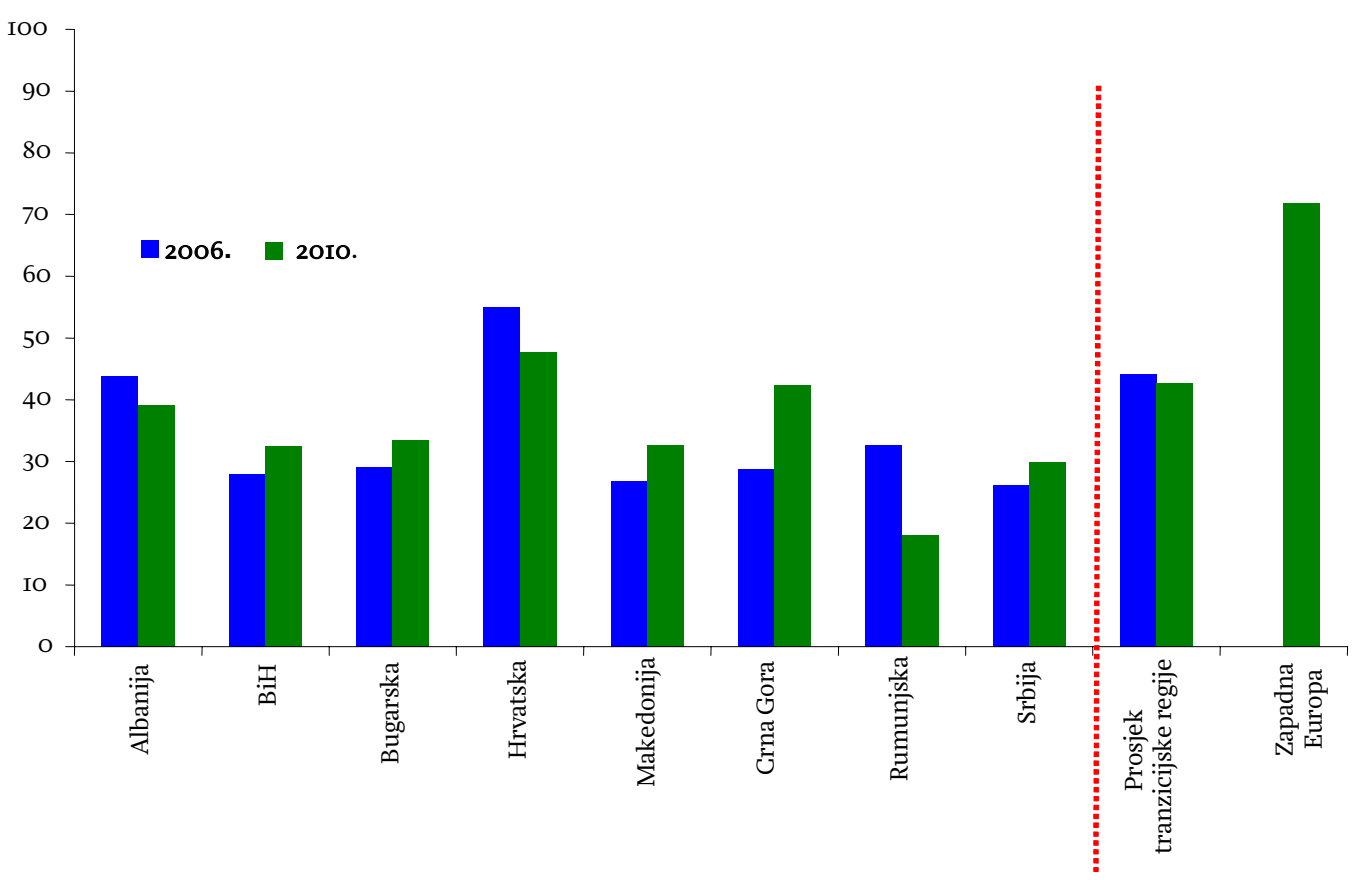

Izvor: EBRD-Svjetska banka, Anketa Life in Transition, 2006. i 2010.

Napomena: Podaci za 20Io. su djelomični. EBRD će objaviti izvještaj o drugom krugu ankete Life in Transition krajem lipnja 2011.

Kako se može potaknuti ekonomski rast? Prilično dosadan odgovor na to pitanje je da održivi rast zahtijeva predanost u provođenju dubinskih strukturnih reformi. Postoje četiri elementa tog plana koja želim istaknuti: reforme, poslovno okruženje, prekogranična razmjena i obrazovanje.

Grafikon 3 prikazuje prosjek rezultata koje je ostvarila svaka država u EBRD-ovom ispitivanju sektorske tranzicije, koje mjeri koliko je napredak ostvarila država u tranziciji prema tržišnom gospodarstvu koje dobro funkcionira. Sustav bodovanja kreće se od I, koji dobijete ako se samo pojavite, do 4,33, što predstavlja stupanj u kojem se može reći da ne postoje ili su ostali zanemarivi tranzicijski izazovi. Grafikon pokazuje da još ima puno posla prije nego što se može proglasiti da je tranzicija završena, čak i u državama središnje Europe, no još više u Jugoistočnoj Europi. 


\section{Grafikon 3.}

Plan rasta: završiti tranziciju

(prosječni rezultati EBRD-a za sektorsku tranziciju, 20Iо.)

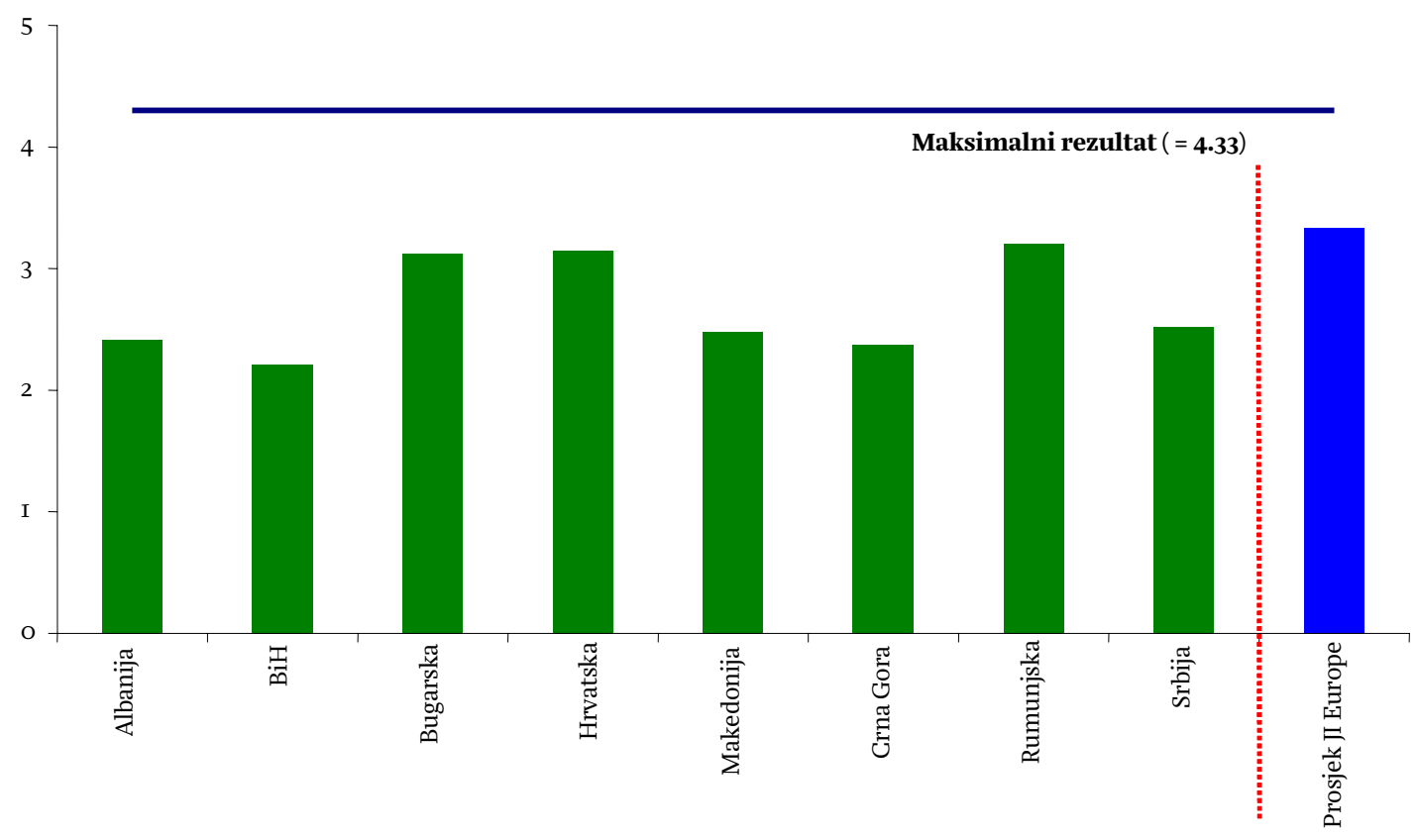

Izvor: EBRD Transition Report, 2010.

Grafikon 4 pokazuje neke od glavnih briga koje su primijetila poduzeća na terenu i otkrili nam ih (i Svjetskoj banci) kroz detaljnu anketu. Problemi s kojima je regija suočena vrlo su raznoliki, no pitanja kao što su porezna uprava, korupcija, nedostatak vještina i loš rad sudova pojavljuju se svugdje. Velika vrijednost tih anketa je da doista iznose probleme s kojima se suočavaju poduzeća na terenu i, nadamo se, mogu usmjeriti vlade koje su odlučne rješavati te probleme. 


\section{Grafikon 4.}

Plan rasta: Rješavanje problema u poslovnom okruženju

(BEEPS 2008./og. - glavne tri prepreke poslovanju, \% odstupanja od prosjeka zemlje)

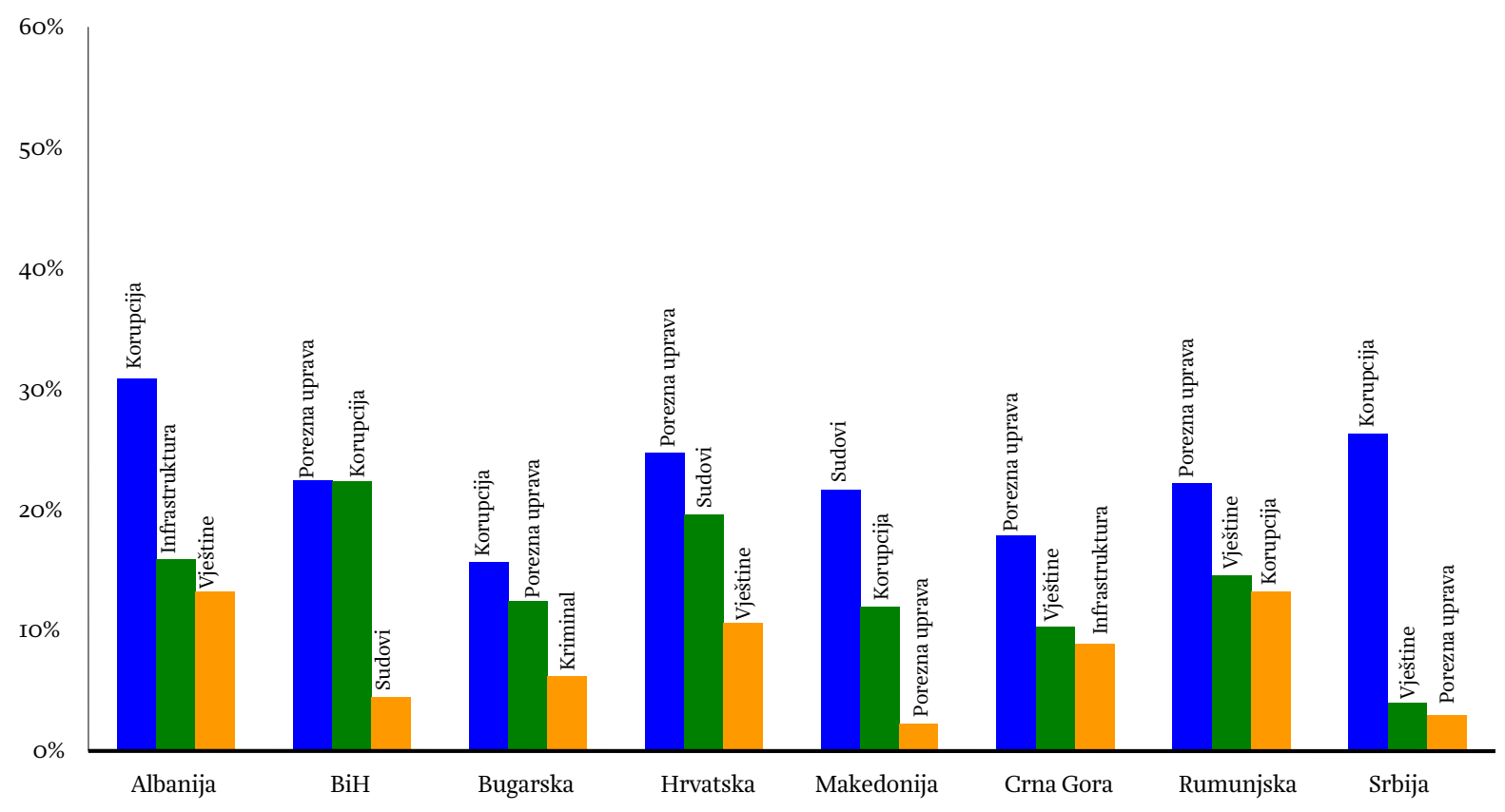

Izvor: EBRD-Svjetska banka, Business Environment and Enterprise Performance Survey, 2008./og.

Još je jedan bitan dio plana rasta, potreba poticanja izvoza, ne samo zbog izravne koristi za bilancu plaćanja, nego i zbog toga što su istraživanja (provedena u EBRD-u i drugdje) pokazala jasnu uzročnu vezu između izvoza i inovacija te istraživanja i razvoja, koji su ključni za rast. Grafikon 5 pokazuje da stupanj otvorenosti Jugoistočne Europe zaostaje za srednjoeuropskim i baltičkim državama. Zašto? Zato što još uvijek postoji mnogo prepreka trgovini - to nisu toliko visoke carine, nego više pitanja loše infrastrukture, neučinkovitosti carinskog sustava i korupcija. 


\section{Grafikon 5.}

Plan rasta: smanjiti prepreke za trgovinu

(otvorenost trgovine ((IZVOZI+UVOZI)/BDP), 2009., \%)

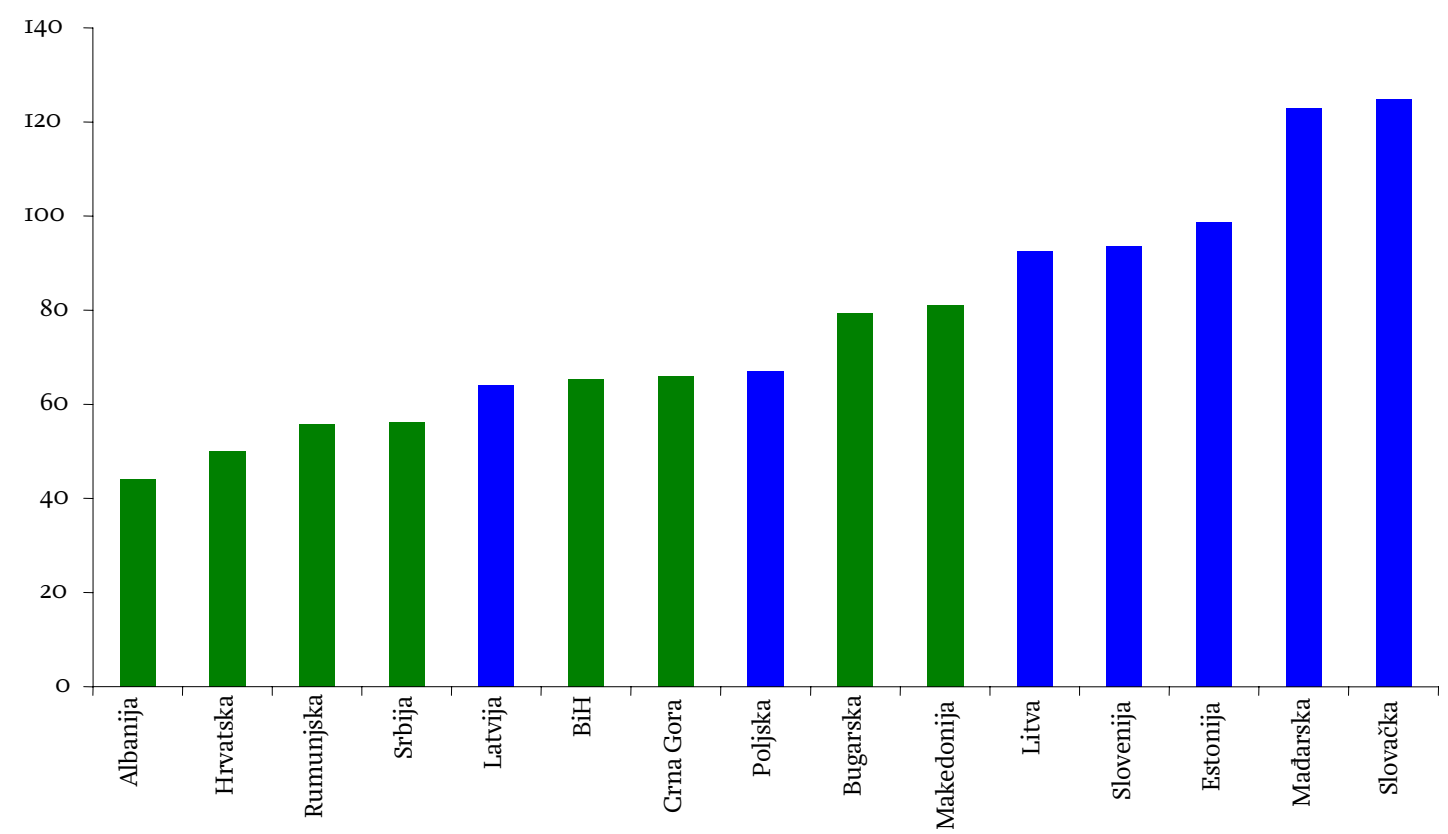

Izvor: Državne vlasti i MMF.

Konačno, kao što je spomenuto, cilj je naših anketa naglasiti nedostatak vještina radne snage - to je posebno bilo izraženo tijekom godina rasta prije krize. U kojoj mjeri gospodarstva na Balkanu pripremaju mlade ljude za osnovna znanja pismenosti, matematike i znanosti? Koristan izvor informacija koje nude pregled po državama o obrazovnim standardima može se naći u takozvanim PISA ispitima I5-godišnjaka u svim zemljama. Grafikon 6. pokazuje da postoje odstupanja u regiji (Hrvatska ostvaruje najbolje rezultate) i da te zemlje još uvijek zaostaju za prosjekom OECD-a. 


\section{Grafikon 6.}

Plan rasta - Potaknuti stupanj obrazovanja

(Programme for International Student Assessment (PISA), rezultati za 2009.)

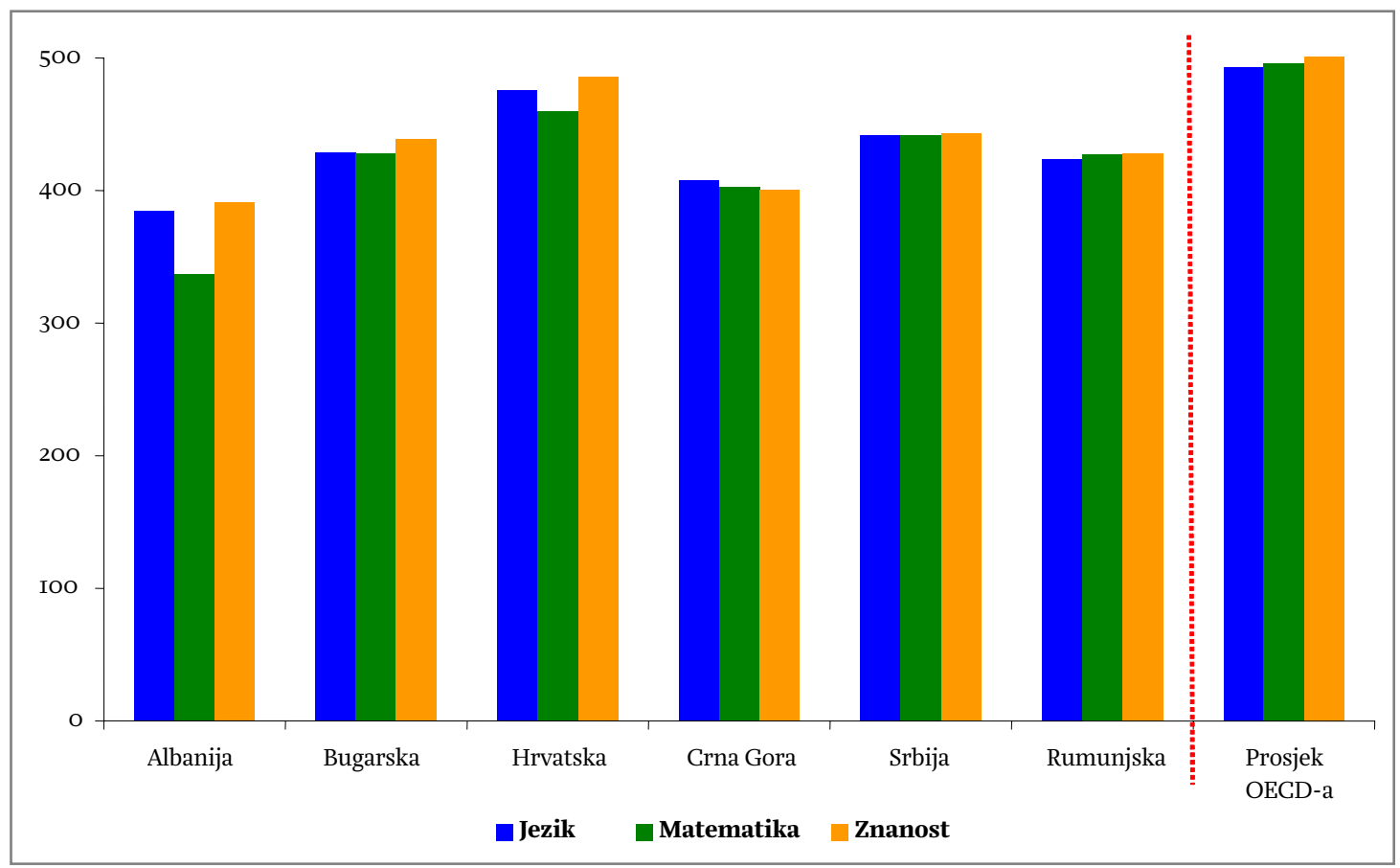

Izvor: OECD.

\section{ZAKLJUČAK}

Chrisova knjiga iz 199I. započela je ironičnom rečenicom „Na Balkanu ništa novo“. Dvadeset godina kasnije, sa sigurnošću može se reći da je situacija mirnija nego što je bila. Svijetu je Balkan manje interesantan nego I990-ih i na tome možemo biti zahvalni. Nekoliko puta dok smo putovali regijom, ljudi su Chrisu i meni rekli da žele živjeti u dosadnoj državi. Jednoga dana ta će im se želja možda ispuniti, no ne još; još uvijek predstoje veliki izazovi, od kojih su samo neki spomenuti u ovom predavanju. Vjerujem da Hrvatska može imati ulogu snažnog vođe i pomoći tom procesu. U mnogo je načina Hrvatska jedinstveno smještena da ostvari tu ulogu, kao most između Jugoistočne i središnje Europe. Sadašnja je vlada jasno izrazila namjeru da podrži i surađuje u potpunosti s regijom, kao i da dovrši pregovore o članstvu s Europskom unijom koji su u tijeku. Ne samo da ja podržavam te napore, nego pouzdano mogu reći da bi ih i Chris podržavao. 